\title{
ÜHEST KATSEST EMOTSIOONIVERBIDEGA
}

\section{Anni Silk}

\begin{abstract}
Ülevaade. Eesti- ja saksakeelsete emotsiooniverbide võrdlevaks semantilis-süntaktiliseks uurimuseks oli kõigepealt vaja koostada loend nimetatud verbide kohta. Seejuures tekkis paratamatult küsimus, mis need emotsiooniverbid õigupoolest on ehk kus on piir emotsiooni- ja mitte-emotsiooniverbide vahel. Ajendatuna arvukatest emotsioonimõistetest ning mitmesugustest emotsioonisõnade nimekirjadest, mille koostajad on eeldatavasti lähtunud erinevatest põhimõtetest, otsustasin küsitleda eesti ja saksa keelt emakeelena kõnelejaid, lastes neil otsustada n-ö piiripealsete sõnade kuulumise emotsiooniverbide hulka. Artiklis antakse ülevaade emotsiooniverbide kindlakstegemisest, kirjeldatakse tehtud katset lähemalt ning püütakse analüüsida saadud tulemusi. Katse tulemused olid mõneti ootuspärased, hõlmates nii üpris üksmeelseid valikuid kui ka vastuolusid näiteks samatüveliste või -sisuliste sõnade hindamisel. Näib, et katseisikud lähtusid sõnade liigitamisel suhteliselt laiast emotsiooniverbide määratlusest, mis hõlmab muu hulgas ka hulgaliselt hinnangulisi kõneaktiverbe."
\end{abstract}

Võtmesõnad: leksikaalne semantika, emotsioonisõnad, eesti keel, saksa keel

\section{Uurimisvaldkond ja eesmärk}

Vajadus koostada emotsiooniverbide nimekiri tekkis seoses mahukama uurimusega, mille eesmärgiks on võrdlevalt uurida emotsiooniverbide semantika ja süntaksi vahelisi seoseid eesti ja saksa keeles. Et uurimusse taheti kaasata võimalikult palju kummaski keeles olemasolevaid emotsiooniverbe, ei sobinud nende kogumiseks välimeetod, nagu seda on kasutanud nt Ene Vainik (2001, 2004), kuna küsitluse käigus ei pruugi katseisikule kõik sõnad meenuda ning osa nimetatud sõnadest kuulub emotsiooniverbide semantilise välja perifeeriasse vaid põhjuslikkuse või assotsiatiivseoste kaudu (Vainik 2002a: 74, 2002b: 548) või jääb sellest rangelt võttes hoopis välja (Vainik 2002b: 548). Kui eesmärk on saada võimalikult täielik pilt

* Artikkel on valminud ETF-i grandi nr 7149 osalisel toel. 
keeles olemasolevatest emotsiooniverbidest, ei ole väga tõenäoline, et keskmisele keelekasutajale meenuvad küsitluse käigus ka harvem kasutatavad tundevarjundeid tähistavad sõnad, ehkki ta neid küll teab ja tunneb. Sellised sõnad on aga samuti emotsioonisõnavara oluline osa.

'Keeleteaduslikuks uurimuseks ei sobi hästi ka psühholoog Jüri Alliku rakendatud meetod, millega valiti emotsioonisõnade nimekirja "enamik eesti keeles sagedamini kasutatavaid ja üldarusaadavaid tundmusi või emotsioone väljendavaid sõnu" (Allik 1996: 8), kusjuures loetelu pidi tingimata sisaldama 60-sõnalise inglise keele emotsioonide nimekirja tõlkevasteid. Kui tahetakse uurida emotsioonisõnu ühes keeles, ei ole mõttekas võtta sõnade nimekirja üle teisest keelest, sest sageli ei ole ühe keele emotsioonisõnale teises keeles täpset vastet ja nii võib tõlkimisel tekkida segadus. Näiteks võib ingliskeelse sõna disgust tõlkida eesti keelde nii 'vastikus, jälkus, tülgastus, tülkus, läilus' kui ka 'kibe pettumus', eesti kahjurõõmule ei ole täpset vastet gruusia keeles ja jaapanikeelsele amae-le ei ole teistes keeltes üldse vastet.

Nimetatud põhjustel otsustasin nii eesti kui ka saksa keele emotsiooniverbid koguda kirjalikest allikatest, nagu seda on teinud ka nt Wilhelm Janke ja Günter Debus (vt Debus 1988), Marcos Herrera Burstein (1997) ning Rolf Kailuweit (2005), kes koostasid nimekirjad peamiselt sõnaraamatutes leiduva keeleainese põhjal. Et uurijad ei ole üheselt defineerinud emotsiooni ja emotsioonisõna, siis sõnastasin enne verbide kogumist olemasolevate käsitluste ning nimekirjade põhjal enda jaoks emotsiooniverbide definitsiooni, mida üritasin nimekirju koostades silmas pidada.

Definitsiooni alusel kogutud verbide seas oli aga terve hulk selliseid, mille puhul ei olnud kerge otsustada, kas ikka on tegemist emotsiooniverbiga. Üks võimalus on sel juhul lasta katseisikutel hinnata, kas või millisel määral sellised sõnad uuritavasse semantilisse välja kuuluvad. Nii toimisingi ebaselge staatusega verbidega - katseisikud said verbide loetelu palvega märkida selles ära sõnad, mis nende arvates on emotsiooniverbid. Kuna puudub objektiivne kriteerium selle kohta, mille alusel mingit sõna emotsioonisõnaks pidada (Tischer 1993: 54), siis otsustasin analoogselt L. Schmidt-Atzertiga (1980) lugeda emotsiooniverbideks sõnad, mida pidasid nendeks vähemalt pooled katseisikutest.

Järgnevalt kirjeldatakse mõnda varasemat uurimust emotsioonisõnade kindlakstegemise kohta, antakse ülevaade tehtud katsest, mille eesmärgiks oli teha kindlaks, milliseid emotsiooniverbide semantilise välja perifeeriasse kuuluvaid verbe peavad emotsiooniverbideks eestlased ning milliseid sakslased, ning võrreldakse saadud tulemusi ja arutletakse nende võimalike põhjuste üle. Eelkõige pidid tehtud katse tulemusena selgunud verbid olema aluseks eesti ja saksa keele emotsiooniverbide võrdlevale semantilis-süntaktilisele analüüsile, ent selgus ka muud huvitavat informatsiooni emotsiooniverbide semantilise välja liigendamise kohta kummaski keeles. 


\section{Emotsioonisõnad ja nende kindlakstegemine}

Sarnaselt emotsioonidega, mida on uuritud ja üritatud defineerida juba antiikajast peale ning mille olemuses ei ole siiani üksmeelele jõutud, ${ }^{1}$ puudub tänaseni ka emotsioonisõnade kindel definitsioon. Sageli on emotsioonisõnadega seotud uurimuste keskmes olnud emotsioonisõnade kategoriseerimine (eri keeltes) (nt Marx 1982, 1997, Schmidt-Atzert 1987, Russell 1991, Allik 1996), hoopis harvem on emotsioonisõnu uuritud nende keelelistest aspektidest (nt Burstein 1997, Siiroinen 2001, Toluk 2002, Kailuweit 2005). Ehkki enamasti ei olegi täpselt defineeritud, mis emotsioonisõnad on, on vahel täpsustatud nende funktsiooni - nii on emotsioonisõnadeks peetud sõnu, mis on keeles emotsioonide või tundmuste tähistamiseks (Õim 1971, Schmidt-Atzert 1987), väljendamiseks (Allik 1996) või iseloomustamiseks (Jäger, Plum 1988), on seotud tajuga ning väljendavad hinnangulisi ja mentaalseid seisundeid ning protsesse (Fries 2007). Lisaks emotsioonisõnade erinevale määratlemisele ning uuritavate sõnade liigilise kuuluvuse ${ }^{2}$ ja hulga varieeruvusele on ka emotsioonisõnu ennast nimetatud erinevalt - affective lexicon 'afektiivne leksikon' (Ortony jt 1987), Gefühlswörter 'tundesõnad' (Fries 2000, 2002, ka Toluk 2005), psychische Wörter 'psüühilised sõnad' (Fries 2007), psych-verbs 'psüühilised verbid' (Klein, Kutscher 2005) või psychological verbs 'psühholoogilised verbid' (Vanhoe 2002, Caluianu 2007).

Olgugi et enamik uurijaid on üksmeelel selles, et emotsioonisõnade semantiline väli on ilma selgete ja üheselt kindlaks määratud piirideta (vt nt ülevaateid Debus 1988, Jäger, Plum 1988) ning et emotsioonisõnade kindlakstegemiseks ei olegi võimalik leida mingeid kriteeriume, mille alusel otsustada, kas sõna on emotsioonisõna või ei ole (Fehr, Russell 1984), on Andrew Ortony, Gerald Clore ja Mark A. Foss (1987) väitnud, et peab olema võimalik tuua välja need reeglid, mille alusel saab määrata, kas sõna kuulub emotsioonisõnade hulka või ei kuulu. Analüüsinud u 500 sõna semantiliselt, jõuavad nad järeldusele, et emotsioonisõnade kõige paremateks esindajateks on sõnad, mis kirjeldavad inimese hinges toimuvaid selge seisundimääratlusega protsesse ja mida saab seostada tunnetest lähtuva hinnanguga mingile objektile, sündmusele või inimesele (Ortony jt 1987: 358). Otsustamisel soovitavad nad kasutada reeglit, mille kohaselt tõelist emotsioonisõna tajutakse sellena nii lauses "Ma olen X" kui ka lauses "Ma tunnen ennast X-ina”. Nii tajutakse sõna angry 'vihane' mõlemas lauses emotsioonisõnana, aga nt abandoned 'mahajäetud' omandab emotsionaalse varjundi alles teises lauses ja sedagi tänu verbile tundma. Seega ei ole mahajäetud tõeline emotsioonisõna (vt Ortony jt 1987: 346-347).

A. Ortony jt (1987) jagavad kogu emotsioonidega seotud sõnavara ehk afektiivse leksikoni kolme alagruppi: sõnad, 1) mis kirjeldavad väliseid olusid (nt abandoned 'mahajäetud', beloved 'armastatud'), 2) millega tähistatakse füüsiliselt tajutavaid seisundeid (nt sleepy 'unine', hungry 'näljane'), ning 3) mis kirjeldavad inimese hingeelu ja psüühilisi või mentaalseid seisundeid. Viimase grupi jagavad nad omakorda pigem kognitsiooniga seotud (interested 'huvitatud'), pigem afektiivsusega

\footnotetext{
1 Erialases kirjanduses leidub kümneid erinevaid emotsioonimääratlusi, alates füsioloogilistest ja neuronaalsetest kuni kognitiivsete ja käitumuslikeni. Kõige sagedamini on emotsioone iseloomustavate tunnustena nimetatud nendega kaasnevat näoilmet, mingile objektile suunatust ja sellele kognitiivse hinnangu andmist, võimatust neid kehas lokaliseerida ning mingit välist ärritajat nende esilekutsujana. Tihtipeale ei esine need tunnused kõik koos, vaid mingi kombinatsioonina, ent üldiselt on emotsioon siiski kompleksne psühhofüsioloogiline protsess, mis tekib vastuseks mingile välisele stiimulile ja mis annab tõuke olla valmis mingiks käitumuslikuks muutuseks (Silk 2006, vt ka Mandl, Euler 1983: 5-11, Ulrich 1989: 31-38, Merten 2003: 13-17, Mitmannsgruber 2003: 15-27).

2 Erinevates emotsioonisõnade nimekirjades on emotsioonisõnadena käsitletud kas ainult adjektiive või ainult substantiive, nii adjektiive kui ka substantiive või sõnu erinevatest sõnaliikidest, st nii substantiive, adjektiive, verbe kui ka adverbe.
} 
seotud (glad 'rõõmus', scared 'hirmunud') ning nii kognitiivse kui afektiivse komponendiga sõnadeks (apathetic 'ükskõikne', discouraged 'heitunud'). Seejuures olevat just teine grupp ehtsad, n-ö kesksed emotsioonisõnad. Lisaks kognitiivsele ja afektiivsele komponendile eristavad A. Ortony jt mentaalsete seisundite kohta käivates sõnades veel käitumuslikku komponenti, mis esineb koos kognitiivse või afektiivse komponendiga.

Ehkki selline sõnade jagamine komponentide alusel näib üsna loogiline ja selgepiiriline, ei ole siiski alati lihtne kindlaks teha, milline komponent mingis sõnas domineerib. Autorid isegi on tunnistanud, et toetuda tuleb pigem intuitsioonile (Ortony jt 1987: 352). Samuti jääb arusaamatuks, miks liigitatakse näiteks aggravated 'ärritatud' ja delighted 'vaimustatud' afektiivsete, aga alarmed 'ärevuses' ja admiration 'vaimustus, imetlus' afektiiv-kognitiivset seisundit väljendavate sõnade hulka või miks ei peeta sõnu baffled 'hämmeldunud' ja amazed 'hämmastunud' afektiivse, vaid kognitiivse komponendiga sõnadeks. Samuti tundub, et tähenduselt sarnased sõnad on kord ühes, kord teises grupis, nt stunned 'vapustatud' loetakse kognitiivse domineeriva, shaken 'vapustatud' afektiivse domineeriva komponendiga sõnaks.

Näiteid emotsioonisõnade määramise vastuolulisusest leiab mujaltki. Näiteks erinevates uurimustes käsitletakse emotsioonisõnadena erinevatesse sõnaliikidesse kuuluvaid sõnu. Valdavalt on emotsioonisõnadena uuritud kas emotsioonimõistetega seonduvaid substantiive (nt Marx 1982, Schmidt-Atzert 1987, 1997, Goozen, Frijda 1993, 1997) või adjektiive (nt Allik 1996) või on uuritud mõlema sõnaliigi esindajaid segamini (nt Õim 1971, Ortony jt 1987, Russell 1991, Frijda jt 1995). Harvem on uurimisobjektiks olnud vaid emotsiooniverbid (nt Siiroinen 2001, Toluk 2002, Kailuweit 2005, Caluianu 2007). E. Vainiku eesti keele emotsioonisõnavara uurimus (2001, 2004) hõlmab keelendeid sõnaliigist sõltumata, kusjuures domineerivad substantiivid (73\%), adjektiive ja verbe on enam-vähem võrdses koguses (Vainik 2002: 252). Küllap on arusaam substantiividest ja adjektiividest kui tüüpilisematest emotsioonisõnadest mõnes mõttes ka mõistetav - moodustavad valdavalt just substantiivid keelekategooriate n-ö põhitasandi (vt nt Kövecses 1995: 4), mis keelt õppides esimesena omandatakse (vt nt Argus 2004: 37) ning mis loetelukatsetes sageli esimesena meenuvad (Vainik 2002), adjektiivi abil aga samastatakse ennast emotsiooniga (nt Ma olen kade) (Allik 1996: 8).

Teiseks võib nimetada märkimisväärseid erinevusi erinevates uurimustes kasutatud emotsioonisõnade loeteludes. See, et põhiemotsioonideks peetav rõõm või kurbus ja nende vasted teistes sõnaliikides esinevad kõigis emotsioonisõnade nimekirjades (Schmidt-Atzert, Ströhm 1983: 131), on üsna loomulik, ent küsitavused tekivad siis, kui üks ja sama sõna (või selle tuletised) kord on, siis jälle ei ole loetud emotsioonisõnaks. Kui võrrelda näiteks A. Ortony jt (1987) koostatud inglis-, Jüri Alliku (1996) ja Ivi Toluki (2002) eesti-, Mari Siiroineni (2001) soome- ning Rolf Kailuweiti (2005) prantsus- ja itaaliakeelset emotsioonisõnade loetelu, siis lisaks nende erinevale pikkusele ning sellele, et kolm viimast koosnevad verbidest, jääb mulje, et just verbid ja nendest saadud tuletised (partitsiibid, kesksõnad) on need sõnad, mis tekitavad vaidlusi oma kuulumise üle emotsioonisõnade hulka. Nii peab vaid R. Kailuweit sks verbe trauen, vertrauen 'usaldama' emotsioonisõnaks, A. Ortony jt liigitavad selle ingliskeelse vaste intimate kognitiivsete mitteafektiivsete meeleseisundite hulka ning ülejäänud kolmes loetelus seda sõna ei esine. Alan- 
dama ja alandatud toovad oma loetelus ära nii J. Allik, I. Toluk kui ka A. Ortony jt (kusjuures ingl submissive 'alandlik, alistuv' ei ole afektiivne seisund ja seega ka mitte n-ö õige emotsioonisõna), R. Kailuweit mainib alandama kui mitte-emotsioonisõna ning M. Siiroineni loetelust selle vastet ei leia. Vastuolusid on veelgi: R. Kailuweit peab emotsiooniverbiks pr se flatter 'lootust hellitama', A. Ortony jt liigitavad ingl expectant ja hopeful '(l)ootusrikas' kognitiivsete mitteafektiivsete meeleseisundit väljendavate sõnade hulka; nii R. Kailuweit kui ka M. Siiroinen välistavad emotsioonisõnadena pr désapprouver 'hukka mõistma', pr reprimander 'taunima' ning sm paheksua 'pahaks panema', sama meelt tundub olevat I. Toluk, samas kui A. Ortony jt nimetavad ingl verbe disapprove-of'pahaks panema' ning sama tüüpi approve-of 'heaks kiitma' afektiivse komponendiga sõnade loendis. Üldse paistab nimetatud uurimuste aluseks olnud loetelusid võrreldes silma, et J. Alliku emotsioonisõnade hulka kuuluvad ka mitmed n-ö iseloomu- või A. Ortony jt liigituse järgi välist olukorda või füüsilist seisundit kirjeldavad sõnad (nt vaenulik, tülinoriv, hooletu, laisk, haiglane, unine, uljas, petetud, mahajäetud). A. Ortony jt kesksete emotsioonisõnade hulgast leiab aga mitmeid üsna ootamatuid sõnu, mida enamasti on peetud pigem kognitiivseteks sõnadeks (nt forgive 'andestama', grateful 'tänulik', hope 'lootma', want 'tahtma').

Nimetatud viies uurimuses toodud sõnaloendeid võrreldes võib öelda, et M. Siiroinen on lähtunud kõige kitsamast emotsiooniverbi määratlusest (loendi tegusõnad on valdavalt seotud asjaomase nimisõnalise emotsiooninimetusega). Ehkki ka I. Toluk olevat lähtunud samadest kriteeriumitest nagu M. Siiroinengi, sisaldab tema sõnaloend pigem kognitiivse komponendiga verbe (nt kahtlema, kõhklema, ebalema), mida ta seostab tundmusega (Toluk 2002: 14), ning ka mitmeid pigem iseloomu kirjeldavate sõnade hulka kuuluvaid verbe (nt julmuma, kalgistama, arastama, julgema, kurjuma, tigetsema, tigestama). Iseloomusõnu esineb suhteliselt palju ka J. Alliku emotsioonisõnade nimekirjas (nt tragi, laisk, vaenulik, jõuline, vapper, haiglane).

Ehkki nendest emotsioonisõnade loenditest kolm on koostatud lingvistilise (eelkõige sõnade süntaktilis-semantilise käitumise, aga ka sõnamoodustuse) uurimuse jaoks (R. Kailuweit, M. Siiroinen, I. Toluk), J. Alliku oma psühholoogias rakendatava positiivsete ja negatiivsete emotsioonide mõõtmise skaala loomiseks ning A. Ortony jt olidki oma uurimuses keskendunud emotsioonisõnade kindlakstegemisele, siis erinev eesmärk ei tundu olevat loetelu koostamist oluliselt mõjutanud. Teistest eristub eespool nimetatud põhjustel vaid pisut M. Siiroineni loetelu.

Loetletud näited peaksid olema ilmekaks tõestuseks, et emotsioonisõnad ei moodusta mingit kindlaksmääratud homogeenset hulka, mida saab ühe reegli abil kindlaks teha ning mis on alati ja ainult emotsioonisõnad. Pigem tuleb nõustuda nendega, kes soovitavad ka emotsioonisõnade ja -mõistete puhul lähtuda prototüübiteooriast (Fehr, Russell 1984, Kövecses 1995: 9), mille kohaselt võrreldakse objekti ja tema omadusi vastava kategooria tüüpilise esindaja ehk prototüübiga. Erinevate kategooriate piirid on hägusad ja üleminekud sujuvad, seega saab ka sõnade kuulumist emotsioonisõnade hulka pidada kas rohkem või vähem tõenäoliseks, mitte tõeseks või valeks. Emotsioonisõnad moodustavad pigem võrgustiku, mille liikmed (ülem-, alam- ja põhitasandi mõisted; erinevatesse sõnaliikidesse kuuluvad sõnad) on omavahel seotud mitmesuguste suhete kaudu. Emotsioonisõnade semantiline väli ei ole homogeenne ega teistest semantilistest väljadest rangelt eraldatud, vaid 
tema n-ö tuum on kompaktne, äärealad aga kattuvad teiste, semantiliselt lähedal seisvate väljade või kognitiivsete valdkondadega (iseloomuomadusi, füüsilisi tundeid ning sotsiaalseid suhteid kajastavad semantilised väljad, vt joonis 1). Tuumiku moodustavad n-ö prototüüpsed emotsioonisõnad, emotsioonide põhinimetustega seonduvad sõnad, nagu viha, kurvastama, rõõmus (neid sõnu mainitakse ka loetelukatsetes sagedamini ja esimestena, Vainik 2001b: 67); semantilise välja äärealal ehk perifeerias paiknevad sõnad, mis võivad kuuluda samal ajal nii emotsiooni- kui ka taju-, meeleolu- või iseloomusõnavarasse ning mille kindla kuuluvuse üle on seega ka raskem otsustada (nt üleannetu, hooletu, uljus, hullus,julgema, sütitama, valutama).

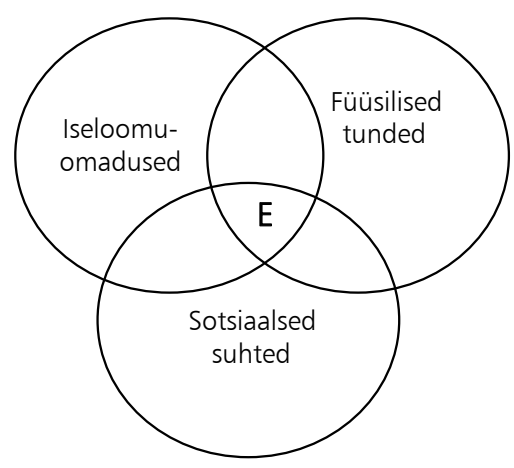

Joonis 1. Emotsioonisõnade semantiline väli (E) teiste semantiliselt lähedaste väljade suhtes. (Joonise koostamisel on võetud aluseks emotsioonikategooria paiknemine Vainik 2004: 39)

Eesti- ja saksakeelsete emotsiooniverbide nimekirja koostama hakates tuli ikka ja jälle esitada küsimus, mis need emotsiooniverbid on ehk kus jookseb puir emotsiooniverbide ja mitte-emotsiooniverbide vahel. Seni kohatud emotsioonisõnade nimekirjades (Ortony jt 1987, Schmidt-Atzert 1987, Tischer 1993, Frijda jt 1995, Allik 1996, Siiroinen 2001, Toluk 2002, Kailuweit 2005) esinenud verbe ${ }^{3}$ võrreldes jagasin emotsiooniverbid enda jaoks kõigepealt kaheks. Emotsiooniverbid kitsamas mõttes tähistavad mingi emotsionaalse seisundi või emotsiooni esilekutsumist, tekkimist või kogemist ning need moodustavad tuumosa ja ka enamuse (nt jahmuma, rõõmustama, vihkama, üllatuma). Emotsiooniverbid laiemas mõttes (perifeeria) hõlmavad tundeeluga üldisemalt seotud verbe, mis ei ole otseselt seotud ühegi kindla emotsiooni või tundeelamusega (nt tundma, tunnetama, aimama) või väljendavad pigem meeleolu, tuju või suhtumist (nt meeldima, sallima, mornitsema, kiuslema). Kuna aga ka meeleolu on seotud tundeeluga, ainult et emotsioonidest eristab seda pikem kestus, väiksem intensiivsus ja puuduv objekt (Schmidt-Atzert 1981: 30, Mitmannsgruber 2003: 30-32), siis lugesin ka need sõnad emotsiooniverbide hulka kuuluvaks. ${ }^{4}$

Ehkki teaduskirjanduses puudub tänaseni ühtne arusaam emotsioonide olemusest ning emotsioonisõnugi ei ole üheselt defineeritud, pidasin siiski mõistlikuks enda uurimuse jaoks emotsiooniverbid täpselt määratleda. Püüdes hõlmata emotsiooniverbe nii kitsamas kui ka laiemas mõttes, defineerisin emotsiooniverbid

3 Frijda jt (1995) käsitlevad nii substantiive, adjektiive, adverbe kui verbe, Schmidt-Atzert (1987) ja Tischer (1993) õigupoolest küll ainult emotsioone tähistavaid substantiive. Substantiivid transformeeriti (nagu Schmidt-Atzert (1981) toimis teiste sõnaliikidega, et saada vaid substantiive) aga verbideks, mis tähistasid omakorda vähem ration 'frustratsioon' - frustreerima). Just viimased on emotsiooniverbid (Kailuweit 2005).

4 Üldise arusaama järgi moodustavad meeleolud emotsioonidele justkui üldise tausta (Mandl, Euler 1983: 6), nii et mingi meeleolu olemasolu soodustab teatud emotsiooni tekkimist, nt agressiivses meeleolus inimene läheb kergemini raevu kui mingis muus meeleolus (vt nt Leising 2003: 31). 
kui verbid, mis kirjeldavad või tähistavad mingeid emotsionaalseid läbielamisi või seisundeid, nende esilekutsumist või tundmahakkamist. Teatud mõttes sisaldab see määratlus liigitust, mida kasutab M. H. Burstein (1997) verbide puhul, mis kirjeldavad emotsionaalseid sündmusi (sks emotionale Ereignisse) - ta käsitleb verbe, mis kirjeldavad seisundeid (nt kurb olema), üleminekuid ühest emotsionaalsest seisundist teise (nt kurvaks muutuma, kurbuma) ning tinglikult öeldes "tegevusi" (sks Handlungen, ingl acts), mis kutsuvad esile emotsiooni (nt kedagi kurvaks tegema, kurvastama). Sarnaselt on tundeverbid määratlenud I. Toluk: "verbid, mis oma tähenduselt väljendasid emotsionaalseid psüühilisi protsesse või tundmusi, samuti emotsionaalse seisundi muutust." (Toluk 2002: 14) Emotsiooniverbi asemel kasutab I. Toluk küll terminit tundeverb, ehkki ta ei käsitle verbe, mis väljendavad füüsilist tunnet. Et tunne võib nii eesti kui ka saksa keeles lisaks emotsionaalsetele läbielamistele ja tundmustele tähistada ka füüsilist aistingut (nt nälja-, valu-, väsimustunne) (Silk 2006, vt ka Fries 2003), siis on käesolevas artiklis eelistatud terminit emotsiooniverb, mis tundub ühemõttelisem.

\section{Materjal ja katse}

Eespool nimetatud emotsiooniverbide määratlust silmas pidades kogusin kättesaadud allikatest, nagu emotsiooniverbiloenditest, emotsioonisõnade nimekirjadest, psühholoogilistes testidest, ÕS 1999-st, EKSS-ist (1988-2005), saksakeelsetest seletussõnaraamatutest (Duden 1996, DWDS), sünonüümi- (Õim 1991, Duden 1997, Görner, Kempcke 1978) ja pöördsõnastikest (Mater 1970) 367 saksa- ja 340 eestikeelset emotsiooniverbi. Loendist jäid välja murdesõnad ning sõnad, mille juures on sõnaraamatus märgend vananenud või vananev. Kogutud sõnade hulgas oli 58 saksa-ja 102 eestikeelset verbi mille liigitumine emotsiooniverbiks oli küsitav. Sellised verbid tähistasid kas üldisi kognitiivseid kogemusi või nende põhjustamist (nt sks beleben 'elavdama', demütigen 'alandama', sich gedulden 'kannatama, kannatlik olema', locken 'meelitama', schönreden 'meelitama'; ee uskuma, veenduma, raatsima), tuju (nt sks gnatzen 'tusatsema', maulen 'mossitama'; ee, mossitama, tigetsema, süngestama) või olid seotud ootuste ja soovidega (nt sks begehren 'ihaldama; soovima, tahtma', erhoffen 'ootama, lootma', gelüsten 'himustama, ihaldama', harren '(pikisilmi) ootama', herbeiwünschen '(kellegi v millegi tulekut) soovima', hoffen 'lootma', schwärmen 'unistama'; ee soovima, tahtma, ootama).

Kuna varasemad uurimused näitasid, et ühtseid kriteeriume emotsiooniverbide määramiseks ei ole ning et tihtipeale ongi nende määramine üsna subjektiivne, tundus mõistlikuna korraldada katse ning lasta emotsiooniverbid määrata kindlaks katseisikutel. Nn ebakindla staatusega verbide nimekiri jagati 76-le saksa keelt (2006. a) ja 47-le eesti keelt (2005. a) emakeelena kõnelejale. Saksakeelsete verbide hindajateks olid peamiselt Kieli Christian Albrechtsi nimelise ülikooli germanistika eriala üliõpilased vanuses 21-32 aastat, lisaks 13 erineval erialal (nt ametnik, õpetaja, majandus, müügitöötaja, kunstnik) töötavat kõrgharidusega inimest Nürnbergis vanuses 31-52 aastat. Eestikeelsed verbid anti hinnata 37-le kõrgharidusega (nt filoloogia, raamatupidamine, õigusteadus, logistika, keemia, bioloogia, geoloogia, stomatoloogia) ja 10-le kesk- või keskeriharidusega (nt raamatupidamine, mehhaanika, kaubandus) eestlasele vanuses 25-71 aastat. 
Katseisikutele anti ülesandeks verbide hulgast välja valida ja alla joonida need, mis nende arvates on emotsiooniverbid, kusjuures rõhutati, et ei ole õigeid ega valesid vastuseid, vaid tahetakse teada üksnes subjektiivset arvamust. Ajapiirangut küsitluslehe täitmisel ei olnud. Eelnevalt tehtud prooviküsitlus näitas, et vaatamata sellele, et oli rõhutatud kõigi vastuste aktsepteeritavust, teatasid mitmed katseisikud, et nemad ei oska vastata, kui ei tea, mis on emotsiooniverb. Et esialgsel verbide valikul kirjalikest allikatest oli lähtutud emotsiooniverbi määratlusest, sai küsitlusele lisatud ka emotsiooniverbi definitsioon. Juurde märgiti, et see võib olla otsustamisel abiks. Oleks ülesandeks olnud lihtsalt katseisiku arvates sobivate sõnade väljavalimine, oleks katse tulemustest saanud ehk leida ka viiteid sellele, kuidas peegelduvad emotsioonid kahe keele maailmapildis. Katse eesmärgiks oli siiski saada enam-vähem sarnastel alustel koostatud nimekirjad, lisaks lasti katseisikutel valida mitte kõigi võimalike sõnade, vaid nende verbide vahel, mille kuulumine emotsiooniverbide hulka ei olnud autorile selge; esialgne valik oli juba tehtud. Ka emakeelsete katseisikute valik ei olnud tingitud mitte soovist saada teavet vastava keele maailmapildi kohta, vaid eeldusest, et emakeeles leiduvad sõnad on katseisikule oma tähenduse ja kasutuse poolest tuttavad.

See, kas ja kui palju kasutasid katseisikud otsustamisel definitsiooni abi, ei ole siiski teada, sest ülesande juhises ei palutud sellest täpselt lähtuda. Võib siiski oletada, et tulemustes peegeldub eelkõige see, mismoodi tõlgendasid katseisikud emotsiooniverbe definitsioonist lähtuvalt (juhul kui nende enda arusaam emotsiooniverbist ei ühtinud küsitluslehel tooduga).

Katse tulemuste tõlgendamisel võtsin eeskujuks L. Schmidt-Atzerti tehtud uuringu (1980), mille käigus lasti katseisikutel hinnata etteantud nimisõnade kuuluvust emotsioonisõnade hulka viiepalliskaalal (4 - kindlasti emotsioon, o - kindlasti ei ole emotsioon). Vältimaks seda, et suure osa etteantud sõnadest paigutavad katseisikud skaala keskele ( 2 - ei tea), nagu juhtus L. Schmidt-Atzerti katses, lasin verbe hinnata vaid sellest seisukohast, kas tegemist on emotsiooniverbiga või ei. ${ }^{5}$ Emotsioonisõnade hulka kuuluvaks luges L. Schmidt-Atzert sõnad, millele katseisikud olid omistanud vähemalt väärtuse 3 (st pigem emotsioon). Sellest lähtuvalt otsustasin, et verbe, mille joonisid emotsiooniverbina alla vähemalt pooled katseisikutest, peetakse suurema tõenäosusega emotsiooniverbiks. Oluline on siinkohal rõhutada tõenäosust, sest väita kindlalt, et väljavalitud sõnad ongi emotsioonisõnad, ei saa. Tegemist on vaid selle katse tulemustega ning mõni teine katse oleks andnud ehk hoopis teise tulemuse. Väljavalitud sõnade kuulumise üle päris lõplikku nimekirja edasiseks analüüsimiseks otsustasin siiski pärast võrdlemist teiste loeteludega.

\section{Tulemused}

102-st eestikeelsest verbist pakkusid katseisikud emotsiooniverbiks umbes pooled 46. Seega jäi eestikeelsesse verbiloendisse kokku 284 verbi (kuna esialgses nimekirjas oli 340 verbi ja 56 verbi puhul oli ülekaalus arvamus, et pigem ei ole tegemist emotsiooniverbiga). Nn valituks osutunud verbide seas oli võimalik leida teatud seaduspärasusi. Näiteks peeti üsna üksmeelselt emotsiooniverbiks halvustamise (alavääristama, halvustama, häbistama, laitma, parastama, pahaks panema,

${ }^{5}$ Siinkohal tuleks mainida ka seda, et L. Schmidt-Atzerti (1980) korraldatud ja käesolevas artiklis kirjeldatud uurimuse eesmärgid olid samuti pisut erinevad, millest oli tingitud ka katseisikutele esitatud ülesande erinev püstitus. L. Schmidt-Atzert soovis teada, millise tõenäosusega peetakse mingit sõna emotsioonisõnaks, siinse artikli eesmärgiks on leida mingigi piir emotsioonisõnade ja mitte-emotsioonisõnade vahel. Lisaks käsitles L. Schmidt-Atzert emotsioonisõnadena vaid nimisõnu, emotsioonisõnavara tüüpilisemaid esindajaid (Vainik 2002b: 542), mitte verbe, nagu siinses uurimuses. 
parastama, vaenutsema, vägivallatsema), tujutsemise (jonnima, kaprïisitsema, tujutsema, kiuslema) ja lõbutsemisega seotud verbe (lustima, lõbutsema, vallatlema), ei peetud aga soovide (ootama, tahtma), uskumise (uskuma, veenduma) ja kannustamisega seotud (õhutama, ärgitama, kannustama) verbe ning üksikuid verbe huvituma, trotsima, morjendama.

Samas võis valikute seas täheldada ka teatud vastuolusid, mis annab ehk taas tunnistust sellest, et nimetatud verbid ei klassifitseeru üheselt ühtegi kindlasse leksikaal-semantilisse välja. Nimelt moodustus terve hulk transitiivseid-intransitiivseid verbipaare (semantiliselt kas kausatiividest ja inhoatiividest või seisundiverbidest) ${ }^{6}$, mille üht liiget pidasid katseisikud emotsiooniverbiks (alljärgnevates sõnapaarides nimetatud esimesena), teist aga mitte (ergutama-ergastama, erkuma; lõõgastuma-lõõgastama; pïnama, pïnlema-pïnutama; rahulduma-rahuldama; süngestuma-süngestama), kusjuures emotsiooniverbiks peetud verb tundub olevat pigem intransitiivne verbivorm.

58 -st saksakeelsest verbist valisid katseisikud emotsiooniverbiks 45, nii et lõpuks jäi saksakeelsesse verbide nimekirja 354 verbi. Ka sakslased pidasid sarnaselt eestlastega emotsiooniverbiks halvustamisega seotud tegusõnu (demütigen 'alandama', entwürdigen 'alandama, häbistama', herabwürdigen 'alandama, alavääristama') ega pidanud uskumisega (schwören 'kindel olema, kindlalt uskuma', sichergehen 'veenduma', überzeugen 'veenma') ning (l)ootusega seotud verbe (sich getrösten 'lootma jääma', gewärtigen 'ootama, lootma'). Samuti moodustusid paarid või grupid sarnase tähendusega (aga erinevalt eesti keelest erineva tüvega) verbidest, millest üks tundus kuuluvat emotsiooniverbide hulka (alljärgnevates sõnapaarides nimetatud esimesena), teine mitte (schmeicheln 'meelitama' schönreden, schöntun 'meelitama'; demütigen, herabsetzen, entwürdigen 'alandama' - herabsetzen 'alavääristama'; sich abgrämen 'murest otsa jääma' - sich abhärmen 'murest otsa jääma'; sich verfinstern, sich verdüstern 'süngestuma' - sich umdüstern 'süngestuma'; aufstacheln, aufmuntern 'reibastama; ergutama' stacheln 'õhutama, ergutama', anregen 'ergutama', beleben 'elavdama, ergutama'; verführen 'kiusatusse viima, ahvatlema' - locken 'peibutama, ahvatlema', verlocken 'ahvatlema, kiusatusse viima'; sich entspannen 'lõõgastuma' - sich abspannen 'lõdvestuma').

Lisaks juba nimetatud sarnasustele eestlaste ja sakslaste sõnavalikus (alandamise, (l)ootuse ja uskumisega seotud sõnad) esines veelgi verbe, mille puhul kummagi keele rääkijad tegid ühesuguse otsuse. Emotsiooniverbiks peeti mõlemas keeles verbe (sulgudes saksakeelne vaste, mis esines saksakeelses nimekirjas) unistama (träumen), lõõgastuma (sich entspannen), andestama (vergeben), süngestuma (sich verdüstern, sich verfinstern); emotsiooniverbiks ei peetud söandama (sich getrauen), roiduma (ermatten), peibutama (locken, verlocken). Ilmnes aga ka erinevusi: kui sakslased pidasid emotsiooniverbiks transitiivseid verbe aufmuntern 'reibastama', ermutigen 'julgustama', aufstacheln 'virgutama, ergutama' (kausatiivid) ning intransitiivset verbi vertrauen 'usaldama' (seisundiverb), siis eestlaste meelest nende sõnade vasted või neile tähenduselt sarnased sõnad ergastama, reibastama; julgema; ärgitama; uskuma emotsioonisõnade hulka ei kuulunud. Rahulduma oli eestlaste arvates emotsiooniverb, sakslaste arvates (vorliebnehmen) mitte, nagu ka eesti rahuldama.

${ }^{6}$ Kausatiivid on alati transitiivsed (Tema sõnad jahmatasid mind), inhoatiivid intransitiivsed (Kati kohkus seda 


\section{Arutelu ja kokkuvõte}

Lahknevused samatüveliste või -tähenduslike sõnade liigitamises ühte või teise gruppi ei iseloomusta vaid seda katset, sama näitas ka lühike ülevaade erinevate autorite koostatud emotsioonisõnade nimekirjadest. Kõigi kirjeldatud katsete tulemusi kõrvutades võib öelda, et katses osalenud isikud on sõnade liigitamisel lähtunud ilmselt emotsioonisõnade laiemast määratlusest, mille kohaselt liigituvad emotsioonisõnade alla ka mitmed kindlat tegevust tähistavad sõnad. Nende all võib esile tuua mitmeid verbe, mis oma olemuselt ei ole otseselt seotud emotsioonidega, vaid nimetavad pigem kõneakte, millega taotletakse kas positiivset või negatiivset muutust teise inimese emotsionaalses seisundis (nt ee alavääristama, alandama, häbistama; sks demütigen, herabwürdigen, entwürdigen 'alandama'), või milles väljendub kõneleja / emotsiooni kogeja hinnang situatsioonile või enda emotsionaalsele seisundile (nt pahaks panema, halvustama, laitma). Vaenutsema on näide suhtumist kirjeldavatest verbidest ning vägivallatsema tähistab negatiivseid emotsioone väljendavat tegevust. Ka E. Vainik on teinud sarnase tähelepaneku, et hinnangulise suhtluse puhul on emotsionaalse mõjutamise komponent olemuslik ning hinnanguliste kõneaktide seostumine emotsiooniverbidega on ootuspärane (Vainik 2007).

Selles mõttes sarnanevad tehtud katse tulemused pigem J. Alliku ja A. Ortony jt kui lingvistide (R. Kailuweit, M. Siiroinen, I. Toluk) nimekirjas leiduvaga. Emotsiooniverbideks ei peetud aga kummaski keeles (l)ootusega seotud verbe, mille on emotsiooniverbide hulka lugenud nii R. Kailuweit (2005) kui ka N. Fries (2000). Uskumuste ja veendumustega seotud sõnade pidamist mitte-emotsioonisõnadeks võib seletada ilmselt sellega, et uskumine ja veendumine (nagu ka ootamine ja lootmine) seostuvad pigem mõistuse kui tunnetega, neis domineerib afektiivse komponendi asemel kognitiivne. Kognitiivsus tundubki olevat see aspekt, mis teeb otsustamise keeruliseks. Tekivad küsimused, kas kognitiivne komponent sõna tähenduses on tugevam kui afektiivne ja kas sõna võib sellegipoolest lugeda emotsioonisõnaks. Kognitiivse komponendiga verbidest peeti emotsiooniverbiks nt ee unistama, andestama, rahulduma; sks träumen 'unistama', vergeben 'andestama', vertrauen 'usaldama'.

Lõbu ja lõbutsemist tähistavate verbide (lustima, lõbutsema, vallatlema) pidamine emotsiooniverbiks on iseenesest loogilinegi - seostub ju omadussõna lõbus (sks lustig) mitte iseloomu, vaid tuju või meeleoluga, tujud ja meeleolud on aga emotsioonidega tihedalt seotud (Schmidt-Atzert 1981: 30, Euler, Mandl 1983: 5-6, Fuchs-Lévy, Greulich-Janssen 1991; Mitmannsgruber 2003: 30-32). Ehkki lõbu kuulub mitmes emotsioonisõnade nimekirjas rõõmu alla (nt Schmidt-Atzert, Ströhm 1983), esineb ta ka omaette emotsioonikategooriana (nt Schmidt-Atzert 1987). Mainitud sõnad väljendavad lisaks pillerkaaritamisele ja vallatuste tegemisele tõepoolest ka vastava tunde või omaduse omamist ("mul on lõbus") või enda samastamist sellega ("ta on vallatu").

Vastupidiselt sakslastele ei ole eestlastest katseisikud pidanud emotsiooniverbideks õhutama, ärgitama, kannustama ja reibastama, vastavasisuline sõnarühm on puudu ka J. Alliku ning I. Toluki sõnaloendist. Sakslased seevastu on transitiivseid verbe (inhoatiive) anspornen 'kannustama', aufmuntern 'reibastama; ergutama, virgutama', aufstacheln 'virgutama, ergutama; tagant kihutama' näinud 
pigem emotsioonisõnana, samuti esineb innustama, sütitama või ärgitama nii R. Kailuweiti, M. Siiroineni kui ka A. Ortony jt sõnaloendis (pr inspirer, šinspirer; sm innostaa, innostua; ingl eager, enthusiastic). Nimetatud sõnadki kannavad endas inimestevahelise suhtlemise seda poolt, mis hõlmab suhtluspartneri mõjutamist ning suunamist. Nähtavasti ei ole nende sõnade semantikas olulisel kohal mitte niivõrd emotsionaalse seisundi muutmine (ärgitamise tulemusel ei muutu ärgitatav ärksaks, nagu ei saa ka öelda, mill(is)eks muutub kannustatav või õhutatav), kuivõrd partneri mõjutamine nii, et see hakkaks midagi tegema.

Erinevalt paljudest emotsioonisõnade nimekirjadest, k.a ülalmainitud, ei peetud tehtud katses emotsioonisõnaks ka verbe huvitama-huvituma. Huvi tundub olevat aga üks neid emotsioonikategooriad, mille kuulumises emotsioonisõnade semantilisse välja ei ole ühel meelel ka kõik emotsiooniuurijad - nii on huviga seotud sõnu käsitlenud oma uurimustes ameeriklased (Averill, Izard, Kotsch), mitte aga rootslased (Ekman, Lundberg) ja sakslased (Schmidt-Atzert, Ströhm) ning need sõnad olevat emotsioonide diferentsiaalskaalal saanud väga madala hinnangu (Schmidt-Atzert, Ströhm 1983: 131).

Silma paistab seegi, et kumbagi keelt kõnelevad katseisikud on otsustanud pigem mitme konkreetset tegevust (nt füüsiline kontakt, hinnanguline verbaalne kommunikatsioon, liikumine ruumis) tähistava verbi (nt ee laitma, vägivallatsema, parastama, vallatlema; sks herabwürdigen 'alandama', verführen 'kiusatusse viima') kui ülekantud tähenduses emotsioonisõnana kasutusel oleva verbi (nt liigutama; berücken 'võluma, lummama', entzaubern 'lummusest vabastama') "kasuks". See võib viidata sellele, et ehkki emotsioonisõnad on sarnaselt emotsioonidele üsna abstraktsed, püütakse neidki endale pisut konkreetsemana ette kujutada. E. Vainiku tehtud vaba loetlemise ülesandes on nimetatud emotsioonidega seonduvate tegusõnade hulgas samuti rohkelt selliseid sõnu, mis väljendavad emotsioone kehakeele, näoilme või mingi tegevuse kaudu (nutmine, naermine, ohkamine), seega konkreetselt ja nähtavalt (Vainik 2002a, 2007).

Tehtud katse tõestas veel kord, et emotsioonisõnade kui kategooria ja semantilise välja piirid on hägusad ning iga keelekasutaja jaoks individuaalsed. Ei ole siis imestada, et nii nagu tänaseni ei ole suudetud üheselt defineerida emotsioone, nii ei ole ka suudetud kokku leppida ühtses emotsioonisõnade definitsioonis. Eesti ja saksa keelt emakeelena kõnelevate katseisikute küsitluse tulemused näitavad, et emotsiooniverbide mõistet tajutakse suhteliselt ebamääraselt, see ei hõlma vaid konkreetsete emotsioonidega seotud või emotsionaalseid seisundeid kirjeldavaid verbe, vaid ka näiteks sõnu, mis tähistavaid tegevusi, mille eesmärgiks on suhtluspartneri emotsionaalset seisundit verbaalselt mõjutada või väljendada hinnangut situatsioonile või partnerile. Keeltevahelistest erinevustest olulisemaks osutusid siiski keelesisesed ning individuaalsed lahknevused - tuli ette ka seda, et tähenduselt sarnaste verbide puhul (nt ergutama-innustama-ärgitama-õhutama) valiti emotsiooniverbide hulka vaid üks või mõned, aga mitte kõik.

Nähtavasti võibki erinevate katseisikutega ja küsitletute hulgaga saada isesuguse tulemuse, kuivõrd emotsioonisõnade näol on tegemist kategooriaga, mida võib tajuda, tõlgendada ja liigitada äärmiselt subjektiivselt. 


\section{Kirjandus}

Allik, Jüri 1996. Eesti keele emotsioone väljendava sõnavara tähendus. - Keel ja Kirjandus 1, 6-12; 2, 92-99.

Argus, Reili 2004. Verbi eelkäijatest esimeste kolmeliikmeliste miniparadigmadeni eesti ja soome keele võrdlusel. - Helle Metslang (koost.), Maria-Maren Sepper, Jane Lepasaar (toim.). Toimiv keel II. Töid rakenduslingvistika alalt. Tallinna Pedagoogikaülikooli eesti filoloogia osakonna toimetised 3. Tallinna Pedagoogikaülikool, Eesti Keele Instituut. Tallinn: TPÜ kirjastus, 37-52.

Burstein, Marcos Herrera 1997. Sprachliches Erfassen von Emotionen im Spanischen: ein Beitrag zur kognitiven Semantik. Inaugural-Dissertation zur Erlangung der Doktorwürde der Philosophischen Fakultät der Albert-Ludwigs-Universität zu Freiburg i. Br.

Debus, Günter 1988. Psychologie der Gefühlswörter. Empirisch-experimentelle Untersuchungsansätze und -ergebnisse. - Ludwig Jäger (Hrsg.). Zur historischen Semantik des deutschen Gefühlswortschatzes: Aspekte, Probleme und Beispiele seiner lexikographischen Erfassung. Aachen, Alamo.

Duden $=$ Duden Deutsches Universalwörterbuch 1996. 3., neu bearb. und erw. Aufl. Mannheim, Leipzig, Wien, Zürich: Dudenverlag.

Duden sinn- und sachverwandte Wörter: Synonymwörterbuch der deutschen Sprache 1997. Herausgegeben und bearbeitet von Wolfgang Müller. Der Duden in 12 Bänden; Bd.8. Mannheim: Dudenverlag.

EKSS = Eesti kirjakeele seletussõnaraamat I-VII. 1988-2007. Eesti Keele Instituut. Tallinn: Eesti Keele Sihtasutus.

Fehr, B; Russell, James A. 1984. Concept of emotion viewed from a prototype perspective. Journal of Experimental Psychology: General, 113, 464-484.

Fries, Norbert 2000. Sprache, Gefühle, Emotionen und Emotionale Szenen. Vortrag zum 65. Geburtstag von Inger Rosengren. Lund.

Fries, Norbert 2003. Gefühlswortschatz im GWDS. - Herbert Ernst Wiegand (Hrsg.). Untersuchungnen zur kommerziellen Lexikographie der deutschen Gegenwartssprache I. Lexicographica, Series Maior Supplementbände zum Internationalen Jahrbuch für Lexikographie 113. Tübingen: Niemeyer.

Frijda, Nico; Markam, Suprapti; Sato, Kaori; Wiers, Reinout 1995. Emotions and emotion words. - James A. Russell, José-Miguel Feranández-Dols, Antony S. R. Manstead, J. C. Wellenkamp (eds). Everyday Conceptions of Emotions. An Introduction to the Psychology, Antropology and Linguistics of Emotion. NATO ASI Series; Series D: Behavioral and Social Sciences 81. Dordrecht, Boston, London: Kluwer Academic Publishers, 121-143.

Fuchs-Lévy, Irmgard; Greulich-Janssen, Gisela 1991. Über das Wesen und die Dynamik des Gefühls. Eine Studie tiefenpsychologisch und philosophisch orientierter Gefühlstheorien in ihrer Bedeutung für die Psychotherapie. Dissertationen im Arbeitskreis für Tiefenpsychologie, Gruppendynamik und Gruppentherapie Berlin, herausgegeben von Prof. Dr. Josef Rattner. Berlin: Verlag für Tiefenpsychologie.

Goozen, Stephanie van; Frijda, Nico H. 1993. Emotion words used in six European countries. - European Journal of Social Psychology, Vol. 23, 89-95.

Görner, Herbert; Kempcke, Günter (Hrsg.) 1978. Synonymwörterbuch: sinnverwandte Ausdrücke der deutschen Sprache. Leipzig: Bibliographisches Institut.

Jäger, Ludwig; Plum, Sabine 1988. Historisches Wörterbuch des deutschen Gefühlswortschatzes. Theoretische und methodologische Probleme. - Ludwig Jäger (Hrsg.). Zur historischen Semantik des deutschen Gefühlswortschatzes: Aspekte, Probleme und Beispiele seiner lexikographischen Erfassung. Aachen: Alamo.

Kailuweit, Rolf 2005. Linking: Syntax und Semantik französischer und italienischer Gefühlsverben. Linguistische Arbeiten 493. Tübingen: Max Niemeyer Verlag. 
Kövecses, Zoltán 1995. Language and emotion concepts. - James A. Russell, José-Miguel Feranández-Dols, Antony S. R. Manstead, J. C. Wellenkamp (eds). Everyday Conceptions of Emotions. An Introduction to the Psychology, Antropology and Linguistics of Emotion. NATO ASI Series; Series D: Behavioral and Social Sciences 81. Dordrecht, Boston, London: Kluwer Academic Publishers,

Leising, Daniel 2003. Veränderungen interpersonal-affektiver Schemata im Verlauf psycholanalytischer Langzeitbehandlungen. Doktorarbeit. Universität Heidelberg.

Mandl, Heinz; Euler, Harald A. Euler 1983. Begriffsbestimmungen. - Harald A. Euler, Heinz Mandl (Hrsg.). Emotionspsychologie: ein Handbuch in Schlüsselbegriffen. U-\&-SPsychologie. München, Wien, Baltimore: Urban \& Schwarzberg.

Marx, Wolfgang 1982. Das Wortfeld der Gefühlsbegriffe. - Zeitschrift für Experimentelle Psychologie, Bd XXIX, H. 1, 137-146.

Marx, Wolfgang 1997. Semantische Dimensionen des Wortfeldes der Gefühlsbegriffe. - Zeitschrift für Experimentelle Psychologie, Bd XLIV, H. 3, 478-494.

Mater, Erich 1970. Rückläufiges Wörterbuch der deutschen Gegenwartssprache. Leipzig: VEB Verlag Enzyklopädie.

Merten, Jörg 2003. Einführung in die Emotionspsychologie. Verlag W. Kohlhammer.

Mitmannsgruber, Horst 2003. Kognition und Emotion. Die Regulation von Gefühlen im Alltag und bei psychischen Störungen. Bern, Göttingen, Toronto, Seattle: Verlag Hans Huber.

Ortony, Andrew; Clore, Gerald L.; Foss, Mark A. 1987. The Referential Structure of the Affective Lexicon. - Cognitive Science 11, 341-364.

Russell, James A. 1991. Culture and the Categorization of Emotions. - Psychological Bulletin 110, 3, 426-450.

Schmidt-Atzert, Lothar 1980. Die verbale Kommunikation von Emotionen: Eine Bedingungsanalyse unter besonderer Berücksichtigung physiologischer Prozesse. Dissertation. Justus-Liebig-Universität Gießen.

Schmidt-Atzert, Lothar 1981. Emotionspsychologie. Kohlhammer-Studienbücher: Psychologie. Stuttgart, Berlin, Köln, Mainz: Kohlhammer.

Schmidt-Atzert, Lothar 1987. Zur umgangssprachlichen Ähnlichkeit von Emotionswörtern. Psychologische Beiträge 29, 140-163.

Schmidt-Atzert, Lothar; Ströhm, Walter 1983. Ein Beitrag zur Taxonomie der Emotionswörter. - Psychologische Beiträge 25, 126-141.

Siiroinen, Mari 2001. Kuka pelkää, ketä pelottaa: nykysuomen tunneverbien kielioppien ja semantiikkaa. Suomalaisen kirjallisuuden seuran toimituksia 844. Helsinki: Suomalaisen kirjallisuuden seura.

Silk, Anni 2006. Gefühl und Emotion in der Sprache. - Anne Arold, Dieter Cherubim, Dagmar Neuendorff, Henrik Nikula (Hrsg.). Deutsch am Rande Europas. Humaniora: Germanistica I. Tartu: Tartu University Press.

Tischer, Bernd 1993. Die vokale Kommunikation von Gefühlen. Fortschritte der psychologischen Forschung 18. Weinheim: Psychologie-Verlags-Union.

Toluk, Ivi 2002. Eesti keele tundeverbid. Bakalaureusetöö. Tartu Ülikool, eesti keele õppetool, käsikiri. Tartu: Tartu Ülikool

Ulrich, Dieter 1989. Das Gefühl. Eine Einführung in die Emotionspsychologie. 2., durchgesehene und ergänzte Auflage. München: Psychologie Verlags Union.

Vainik, Ene 2001. Eestlaste emotsioonisõnavara. Magistritöö. Tartu Ülikool, eesti keele õppetool, käsikiri. Tartu: Tartu Ülikool

Vainik, Ene 2002a. Kas eestlased on "kuumaverelised"? Eestlaste rahvalikust emotsioonikategooriast. - Mati Erelt (peatoim.), Evi Ross, Asta Õim (toim.). Emakeele Seltsi aastaraamat 47 (2001). Tallinn: Emakeele Selts, 63-86.

Vainik, Ene 2002b. Millest on tehtud eestlaste emotsioonisõnavara? - Keel ja Kirjandus 8, 537-553. 
Vainik, Ene 2004. Lexical Knowledge of Emotions: the Structure, Variability and Semantics of the Estonian Emotion Vocabulary. Dissertationes linguisticae universitatis Tartuensis 5. Tartu: Tartu University Press.

Vainik, Ene 2007. Emotsioonisõnad töises keskkonnas - millest kõnelevad loetelukatsete tulemused? - Helle Metslang, Margit Langemets, Maria-Maren Sepper (toim.). Eesti Rakenduslingvistika Ühingu aastaraamat 3. Estonian Papers in Applied Linguistics 3. Tallinn: Eesti Keele Sihtasutus, 339-353.

Õim, Asta 1991. Sünonüümisõnastik. Tallinn: Autori kulu ja kirjadega.

Õim, Haldur 1971. Isiku mõistega seotud sõnarühmade semantiline struktuur eesti keeles. Keele modelleerimise probleeme 4. Tartu Ülikooli toimetised 278. Tartu, 5-260.

\section{Võrgumaterjalid}

Caluianu, Daniela 2007. Psychological Verbs and the Transitivity in Romanian, English and Japanese. http://www3.aa.tufs.ac.jp/ ritsuko/project/calu9810.html (27.03.2007)

DWDS = Das Digitale Wörterbuch der deutschen Sprache des 20. Jh. http://www.dwds. $\mathrm{de} /($ 10.09.2006)

Fries, Norbert 2002. Emotionen. Linguistische und kognitionswissenschaftliche Aspekte ihrer Explikation. http://www2.rz.hu-berlin.de/inside/linguistik/institut/syntax/ download.htm\#Materialien (29.04.2005)

Fries, Norbert 2007. Die Kodierung von Emotionen und Texten. - Journal of Literary Theory 1 (2). http://www2.hu-berlin.de/linguistik/institut/syntax/docs/fries2007a. pdf (15.06.2007)

Klein, Katarina; Kutscher, Silvia 2005. Lexical Economy and Case Selection of Psych-Verbs in German. http://www.linguistics.ruhr-uni-bochum.de/ klein/papers/LexEconPsych. pdf (27.03.2007)

Vanhoe, Henk 2002. Aspects of the syntax of psychological verbs in Spanish. A lexical functional analysis. - Miriam Butt, Tracy Holloway King (eds). Proceedings of the LFGo2 Conference. National Technical University of Athens. CSLI Publications. http:cslipublications.stanford.edu/LFG/7/lfgo2vanhoe.html (27.03.2007)

Anni Silk (Tartu Ülikool) on lõpetanud Tartu Ülikooli saksa filoloogia erialal. Kaitses samas ülikoolis 2002. a magistrikraadi võrdlevast leksikaalsest polüseemiast. Alates 2003. a töötab kontrastiivse lingvistika teadurina. Uurimisvaldkonnad: polüseemia, leksikaalne semantika, kontrastiivne lingvistika, valents, emotsiooniverbid.

Anni.Silk@ut.ee 


\section{ÜBER EIN EXPERIMENT MIT EMOTIONSVERBEN}

\section{Anni Silk}

Universität Tartu

Beim Zusammenstellen der estnischen und deutschen Emotionsverblisten entstand immer wieder die Frage, was die Emotionswörter (in diesem Fall Emotionsverben) eigentlich sind. Verschiedene Wortlisten in der Literatur scheinen nach völlig verschiedenen Kriterien zusammengestellt zu sein. Einige Autoren (z. B. Mari Siiroinen) gehen anscheinend von einer recht begrenzten Emotionswortbestimmung aus, nach der Emotionsverben fast ausschließlich mit bestimmten Emotionen in Zusammenhang stehen, nach anderen (z. B. Jüri Allik, Andrew Ortony, Gerald L. Core und Mark A. Foss) umfassen diese auch einige weitere kognitive Wörter bzw. Wörter, die eher Charaktereigenschaften bezeichnen.

Um festzustellen, welche Verben estnische und deutsche Muttersprachler als Emotionsverben empfinden, wurden 76 deutsche und 47 estnische Versuchspersonen gebeten, über die Zugehörigkeit der vorgegebenen (und vorher als sog. Grenzfälle bezeichnenden) Verben zum Wortfeld der Emotionsverben zu entscheiden. Die Ergebnisse des Experiments zeigen, dass sowohl Deutsche als auch Esten im Allgemeinen eher konkrete Tätigkeitsverben (wie z. B. laitma 'tadeln', schmeicheln) als Verben mit übertragener Bedeutung (wie z. B. berücken, entzaubern) zu Emotionswörtern zählen und Emotionsverben als ein ziemlich weites Wortfeld betrachten, zu dem auch mehrere (bewertende) Sprechaktverben (z. B. demütigen, entwürdigen, herabwürdigen). Besonders schwankend schienen die Entscheidungen bei Verben mit der kognitiven Komponente zu sein - ein Teil von ihnen wurde für Emotionsverben gehalten, ein anderer dagegen nicht.

Es sollte noch bemerkt werden, dass die Unterschiede zwischen Individuen und innerhalb einer Sprache wesentlich größer waren als die zwischen Deutsch und Estnisch. Das beweist nochmals, dass Emotionswörter ein Gebiet mit sehr subjektiven Grenzen und Kriterien darstellt.

Schlagwörter: lexikale Semantik, Emotionswörter, Estnisch, Deutsch 